\title{
Conferences and Announcements
}

\section{Jesuit Survival and Restoration \\ 2ooth Anniversary Perspectives from Boston and Macau \\ An International Conference, 11-15June, 2014, Boston College*}

\section{(updated)}

2014 marks the 20oth anniversary of the restoration of the Society of Jesus, one of the most significant events in nineteenth-century cultural and religious history but also one of the least well-studied. This international conference aims to shed new light on neglected aspects of this vital subject.

The 1773 suppression of the Jesuits, and the various national expulsions and banishments that preceded it, sought to destroy the Society as a corporate entity. This did not spell the end of the Jesuit enterprise, however. Persecuted by the Catholic monarchies of Portugal, Spain, and France, the Jesuits survived in various guises and locales across the globe. We focus on three of these and the links between them but we also look at the parallel contexts in other parts of Asia, South and North America, and central and western Europe.

The eastern part of the Commonwealth of Poland-Lithuania, known as Belarus or White Russia, was occupied by Catherine the Great just before the papal suppression of the Order. She rejected the ratification of the papal brief of suppression in her territories. Local Jesuits not only continued to influence the region's religious history but also expanded their influence beyond the safe haven of the Russian Empire. One of the most striking examples was their enterprise in China. From their intellectual center in Połock-dubbed the Athens of Belarus - they attempted to re-approach China through their easternmost station in Irkutsk, Siberia and their community in St. Petersburg. Exiled Jesuits from Portuguese Macau also found refuge in continental

\footnotetext{
* The Jesuit Institute at Boston College http://www.bc.edu/content/bc/centers/jesinst.html
} 
China, where the Society sustained its pivotal role in the historic encounter between East and West, initiated by the Italian Matteo Ricci back in the 16th century.

Just as significant was the role of ex-Jesuits in the religious landscape of the fledgling United States and the links between Jesuit survival in Eastern Europe and North America were crucial. Five former Jesuits in the United States renewed their vows in 1805 (a decade before the order's official restoration) after receiving permission from Russia and even when the Jesuit presence in Russian territory became increasingly controversial during the first two decades of the nineteenth century the dynamism continued. The Polish Superior General Tadeusz Brzozowski sent a group of his confreres to Boston. There, and in other parts of the United States, the Society would thrive throughout the early nineteenth century. They would be crucial, for instance, in saving Bishop John Carroll's struggling Georgetown College and in establishing new institutions and missions across the United States.

The history of the Society's survival after 1773 and its restoration two centuries ago deserve closer attention and the anniversary year of 2014 provides an ideal opportunity. We plan to look at three hotspots, arguably the three most important engine-rooms of Jesuit activity during this turbu- lent period: eastcentral Europe/Russia, China, and the United States and place them within the context of other regions of the globe. What happened in and between these far-flung places defined the future of the Jesuit order and also had momentous consequences for the broader religious and cultural history of three continents. Adopting a global perspective and recruiting some of the finest scholars working in this muddled but fascinating field will go a long way toward plugging a lamentable historiographical hole.

\section{WEDNESDAY, 11 JUNE}

4:00-6:0oPM

Introduction to Conference: Robert A. Maryks and Jonathan Wright

Welcome: Dean David Quigley and T Frank Kennedy, S.J.

Keynote Speaker: John W. O'Malley, S.J. Informal Introductions

\section{THURSDAY, 12 JUNE}

9:00AM-11:0oPM

Panel I: THE HISTORICAL CONTEXT 
1. Jesuit Survival and Restoration: A Historical Context, Robert A. Maryks (Boston College)

2. Jesuits post-1814: A Restored Society of Jesus or a New Society of Jesus? Thomas Worcester, S.J. (College of the Holy Cross, Worcester (MA))

3. Some Remarks on Jesuit Historiography 1773-1814, Robert Danieluk, S.J. (ARSI, Rome)

4. Papal Discontent and the Centennial Anniversary of the Restored Society, Peter Bernardi, S.J. (Loyola University, Chicago)

11:15-1:00PM

Panel II: THE COMMONWEALTH OF POLAND-LITHUANIA AND THE RUSSIAN EMPIRE

5. Before and After Suppression: Jesuits and Former Jesuits in the PolishLithuanian Commonwealth, 1763-1795, Richard Butterwick (University College London)

6. The Society of Jesus in the Russian Empire (1772-1820) and the Restoration of the Order (1814), Marek Inglot, S.J. (Pontifical Gregorian University, Rome)

7. Sebastian Sierakowski, S.J. and the Language of Architecture in EarlyNineteenth Century Galicia, Carolyn C. Guile (Colgate University, Hamilton $[\mathrm{NY}]$ )

3:00-5:00PM

Panel III: CENTRAL AND WESTERN EUROPE I

8. The Jesuits and their Artistic Diaspora in Germany, Jeffrey Chipps Smith (University of Texas at Austin)

9. Enduring the Deluge: Hungarian Jesuit Astronomers from Suppression to Restoration, Paul Shore (St. Paul's College, University of Manitoba, Winnipeg)

10. "By any other name": Retaining a Jesuit Identity in England during the Suppression, Thomas McCoog, S.J. (Fordham University, New York City)

\section{FRIDAY, 13 JUNE}

9:00AM-11:0oPM

Panel IV: CENTRAL AND WESTERN EUROPE II 
11. Exiled Spanish Jesuits and the Restoration of the Society of Jesus, Niccolò Guasti (Università degli Studi di Foggia)

12. The Society of Jesus Under Another Name. The Paccanarists in the Restored Society of Jesus, Eva Fontana Castelli (Rome, independent scholar)

13. Between Suppression and Restoration in Italy: Luigi Mozzi de' Capitani (1746-1813), Emanuele Colombo (DePaul University, Chicago)

11:15-1:0oPM

Panel V: CHINA AND BEYOND I

14. Twilight of the Jesuit China Mission, 1750-180o, Ronnie Po-chia Hsia (Pennsylvania University State)

15. Restoration or Recreation? The Return of The Society of Jesus to China, Paul Rule (La Trobe University, Melbourne)

16. Rising from the Ashes: the Gothic Revival and the Architecture of the New Society of Jesus in China and Macao, César Guillen (Macau Ricci Institute)

17. Chinese Music and Church Songs at the French Jesuit Church in Beijing at the End of the 18th Century, François Picard (Université Paris-Sorbonne)

2:0oPM

Visit to the Exhibition "Jesuit Survival and Restoration" and "The Jesuit Victorian Poet Gerard Manley Hopkins" at John J. Burns Library, Boston College

Free afternoon

\section{SATURDAy, 14JUNE}

9:00AM-11:0oPM

Panel VI: CHINA AND BEYOND II

18. The Phoenix Rises from its Ashes: The Restoration of the Jesuit Shanghai Mission, Paul Mariani, S.J. (Santa Clara University)

19. The Long Shadow of the Rites Controversy on a New Generation of China Jesuits, Jeremy Clarke, S.J. (Boston College)

20. From Polotsk to Kiakhta: Jesuit Survival and Russo-Chinese Diplomacy, Greg Afinogenov (Harvard University) 
21. The Jesuits in India between the Old and the New Society of Jesus, Sabina Pavone (University of Macerata)

11:15-1:00PM

Panel VII: THE AMERICAS I

22. Understanding Jesuit Restoration: The American Experience, Jonathan Wright (Durham University)

23. The "Russian" Society and the American Jesuits: Giovanni Grassi's Crucial Role, Daniel Schlafly (St. Louis University)

24. The Restoration in Canada: A Troubled Inheritance, John Meehan, S.J. (Campion College, Regina [Canada]) and Jacques Monet, S.J. (Regis College, Toronto)

1:00-3:00PM

Panel VIII: THE AMERICAS II

25. The Restoration of the Society of Jesus and Latin America, Jeffrey Klaiber S.J. (Pontifical Catholic University of Peru, Lima)

26. Jesuit Tradition and the Rise of South-American Nationalism, 1782-1810, Andrés Prieto (University of Colorado at Boulder)

27. The First Return of the Jesuits to Paraguay, Ignacio Telesca (Consejo Nacional de Investigaciones Científicas y Técnicas, Buenos Aires)

28. The Restoration of the Jesuits in Mexico: Some Historiographical Remarks, Perla Chinchilla (Universidad Iberoamericana, Mexico City)

\section{SUNDAY, $15 \mathrm{JUNE}$}

10:00AM-12:0oPM

Panel IX: AFRICA

29. The Restoration in Africa-an Overview, Festo Mkenda, S.J. (Jesuit Historical Institute in Africa, Nairobi)

30. The Survival of the Jesuits in Southern Africa after the Restoration of the Society of Jesus (1875-19oo), Aquinata Nanyonjo Agonga (Jesuit Historical Institute in Africa, Nairobi)

31. The Post-Restoration Jesuit Mission in Fernando Po, 1859-1871, Jean Luc Enyeque, S.J. (Boston University) 


\section{2:15PM-13:15PM}

Roundtable Panel (coordinated by John Padberg, S.J., St. Louis University): What have we learned? Where do we go from here? 


\section{Encounters between Jesuits and Protestants in Asia}

The Macau Ricci Institute, 9-11 November 2016

\section{Call for Papers}

The approaching 50oth anniversary of the Protestant Reformation (1517) provides an ideal opportunity to reflect in a deeper and new way on the history of the relationship between the Protestants and the Jesuits who were founded twenty-three years later (1540). For better or worse, much ink has been used to write about their animosity, especially in the European context. While this important historical chapter will be explored in other venues, the international conference in Macau aims to re-examine the encounters between the Jesuits and the Protestants and their respective traditions in the context of Asia. Supported by the Catholic monarchies of Portugal, Spain, and France, the Jesuit order played a significant role in bringing Christianity and European culture, sciences, and the arts to Asia from the sixteenth through to the late eighteenth century, when a Franciscan pope suppressed the Jesuits. After the restoration of the order by another pope (1814), the Jesuits returned to several Asian countries at various historical moments and they found more Protestant missionaries than they left a few decades earlier. Indeed, the latter intensified their missionary efforts through the nineteenth and twentieth centuries with the rise of the imperial powers of Great Britain, France, and the US in the region. This historical development lends itself to an obvious comparison between the Jesuit and Protestant methods of presenting Christianity to Asian societies, in which — with the exception of the Philippines that followed the path of Latin America-Christians never became a majority.

The Jesuits themselves, however, used different strategies in different cultural circumstances. Francis Xavier who was among the first Europeans to approach Japan employed different methods than did Matteo Ricci who was allowed to enter the Forbidden City. Roberto de Nobili's missionary style in the caste-divided society of Madurai was different from that of Alexandre de Rhodes who penetrated the Kingdom of Annam. In spite of this variety of approaches within the Society of Jesus itself, accommodation became a trademark of Jesuit missions.

Knowing that charges of syncretism were a mainstay of Protestant antiJesuit polemic, a question that comes to mind, then, is what was the extent to which the generations of Protestant missionaries in Asia adopted Jesuit approaches to cultural accommodation. What were their approaches to studying and codifying local languages, to transmitting Western science? What was 
the relationship between missionaries and political/commercial elites on both sides of the confessional divide? When the Jesuits themselves began rebuilding their missions after the restoration, did they continue their pre-suppression traditions? The cooperation and conflict between the Dutch merchants and the Jesuit missionaries in Japan appears to be better studied but can the same be said about the encounters between the Jesuits and the Protestant Dutch missionaries in Taiwan and Malacca, or between the Jesuits and the German Pietist missions in China and India? How did the Jesuits relate to their Protestant colleagues in the competition to gain Asian souls, say, in late nineteenth-century Korea? These are just a few examples of complex questions about the encounters between the Jesuits and the Protestants, and their tradi- tions, that this international conference hopes to explore in an interdisciplin- ary academic conversation in Macau - a city that lay at the crossroads of European explorations of Asia.

Please email a short (200-250 words) abstract of a proposed paper to both Dr. Ronnie Po-chia Hsia (rxh46@psu.edu) and Dr. Robert A. Maryks (maryks@ bc.edu) before 31 May 2014. The abstract must be written in standard academic English. If accepted, the author will be expected to deliver his/her paper in standard academic English. Selected papers will be published either in a dedicated volume or in the Journal of Jesuit Studies (Brill). 


\title{
Encounters between Jesuits and Protestants in
} Africa

\author{
Jesuit Historical Institute in Africa Nairobi, Kenya, \\ 28June-1July 2016
}

\section{Call for Papers}

The approaching 5ooth anniversary of the Protestant Reformation (1517) provides an ideal opportunity to reflect in a deeper and new way on the history of the relationship between the Protestants and the Jesuits who were founded twenty-three years later (1540). For better or worse, much ink has been used to write about their animosity, especially in the European context. While this important historical chapter will be explored in other venues, the international conference in Nairobi aims to re-examine the encounters between the Jesuits and the Protestants and their respective traditions in the context of Africa. Supported by the Catholic monarchy of Portugal, the Jesuit order played a significant role in bringing Christianity and European culture to Africa from the mid-sixteenth through to the late eighteenth century, when the pope suppressed the Jesuits.

After the restoration of the order by another pope (1814), the Jesuits returned to several African countries at various historical moments and they found more Protestant missionaries than they left a few decades earlier. Indeed, the latter intensified their missionary efforts through the nineteenth and twentieth centuries with the rise of the imperial powers of Great Britain, France, Germany, and Belgium in the region. This historical development lends itself to an obvious comparison between the Jesuit and Protestant methods of presenting Christianity to African societies.

The Jesuits themselves, however, used different strategies in different cultural circumstances. Andrés de Oviedo, auxiliary bishop to João Nuñes Barreto, the Jesuit patriarch of Ethiopia, employed different methods than did Gonçalo da Silveira in his brief mission to the Makaranga tribes in the Southeast. Baltasar Barreira's missionary style among the Angolans was different from that of João de Paiva who built the education system in Kongo. In spite of this variety of approaches within the Society of Jesus itself, accommodation became a trademark of Jesuit missions.

Knowing that charges of syncretism were a mainstay of Protestant antiJesuit polemic in Europe, a question that comes to mind, then, is what was the extent to which the generations of Protestant missionaries in Africa, such as 
Dutch missionaries in Cape Town, adopted Jesuit approaches to cultural accommodation. What were their approaches to studying and codifying local languages, to transmitting Western culture? What was the relationship between missionaries and political/commercial elites on both sides of the confessional divide? When the Jesuits themselves began rebuilding their missions after the restoration, did they continue their pre-suppression traditions? These are just a few examples of complex questions about the encounters between the Jesuits and the Protestants, and their traditions, that this international conference hopes to explore in an interdisciplinary academic conversation in Nairobi.

Please email a short (200-250 word) abstract of a proposed paper to both Dr. Festo Mkenda (jhiafrica.director@jesuits.net) and Dr. Robert A. Maryks (maryks@bc.edu) before 31 May 2014. The abstract must be written in standard academic English. If accepted, the author will be expected to deliver his/her paper in standard academic English. Selected papers will be published either in a dedicated volume or in the Journal of Jesuit Studies (Brill). 